\title{
A dimensão da noite em Novalis e Trakl
}

LAUra MoOsburger - USP

\section{Introdução}

Lugar do inconsciente e do sonho, no qual o desejo romântico de fusão com o universo encontra ressonância, a noite é motivo predominante na literatura do Romantismo, tendo n' $O s$ Hinos à Noite de Novalis uma de suas mais conhecidas expressões. Nessa obra a noite é apresentada positivamente, como a dimensão da "verdadeira vida", que nasceria da experiência da morte e, num processo de conversão, terminaria por revelar a própria morte como uma fusão com o todo. Dentre os autores do século XX que, bebendo nas fontes do Romantismo, retomam o tema da noite, destaca-se Georg Trakl, um expressionista de sensibilidade romântica e grande admirador de Novalis que, de par com o desamparo espiritual próprio de seu tempo, apresenta em sua lírica uma perda da dimensão positiva e acolhedora da noite e uma consequente queda para a dimensão negativa de uma noite desoladora, que não mais representa a morte como ascensão e renascimento, mas sim como queda e deterioração. 
Agora, em vez de favorecer uma fusão com o universo, como em Novalis, a dimensão da noite passa a exprimir a impossibilidade dessa fusão. Para explorar esse movimento propomos uma leitura comparativa do primeiro Hino à Noite de Novalis - no qual está contido o cerne de sua concepção da noite - e dos poemas "Ocaso", "Cântico da Noite XII" e "A melancolia" de Trakl, em que a dimensão negativa da noite se mostra preponderante.

\section{A noite acolhedora de Novalis}

Dentre os seres vivos que têm o dom da sensibilidade haverá algum que não ame, mais do que todas as aparições feéricas do extenso espaço que o rodeia, a luz, em que tudo rejubila as suas cores, os seus raios, as suas vagas; e a suave omnipresença do seu dia que desponta? Como se fora a alma mais íntima da vida, respira-o o gigantesco orbe dos astros sem repouso, que flutua dançando no seu fluxo azul - respira-a a pedra faiscante, em sempiterna paz, as plantas sugadoras e meditativas, e os animais selvagens e ardentes, de tão várias figuras - todavia, mais do que todos, respira-a o excelso Estrangeiro, de olhar pensativo, passos incertos, lábios docemente apertados e repletos de harmonias. Como um rei da terrestre Natureza, ela convoca todas as potências para inúmeras transformações, prende e desprende perenes vínculos e envolve todos os seres terrenos na sua celeste imagem. Somente pela sua presença desvela toda a maravilha dos 
impérios do mundo (Novalis, 1998, p. 17) ${ }^{1}$

O primeiro dos Hinos à Noite de Novalis começa com um louvor ao dia, que o eu lírico introduz mediante uma pergunta em tom nitidamente retórico, e que destaca a luz como a dimensão de uma exuberância infinita que "a tudo encanta com as suas cores, raios e vagas" e com a plenitude da "suave onipresença do seu dia que desponta". Tal plenitude, ressaltada pelo prefixo all- (oni-) tanto em allerfreulich ("que a tudo encanta", ao pé da letra "oniencantador") e Allgegenwart ("onipresença"), ganha na sequência a imagem de uma verdadeira 'alma do mundo', ao ser cantada como "a alma mais íntima da vida" que é respirada pelo "gigantesco orbe dos astros sem repouso que flutua dançando no seu fluxo azul", pela "pedra faiscante em sempiterna paz", pelas "plantas sugadoras e meditativas", pelos "animais selvagens e ardentes de tão várias figuras" e, mais do que todos, pelo homem, que surge na figura de um "excelso Estrangeiro, de olhar pensativo, passos incertos, lábios docemente apertados e repletos de harmonias". A luz é considerada aqui a fonte que nutre todas as formas de ser, da pedra ao homem, e reveladora do espetáculo do mundo: "somente pela sua presença desvela toda a maravilha dos impérios do mundo". Só por isso ela já possui uma dignidade ontológica inquestionável. Mas essa dignidade vai mais longe, porque, mais do que desvelar as maravilhas do mundo, a luz as coloca em movimento, como uma potência vital que gera os ciclos da vida: "como um rei da terrestre natureza,

${ }^{1}$ Utilizamos aqui a tradução portuguesa de Fiama Hasse Pais Brandão, comparando-a sempre que necessário com a brasileira de Nilton N. Okamoto e Paulo Allegrini (vide referências bibliográficas). Agradecemos a Marta Kawano pelas sugestões feitas quando da apresentação do texto no colóquio Romantismo e Literatura. 
ela convoca todas as potências para as inúmeras transformações, prende e desprende perenes vínculos e envolve todos os seres terrenos na sua celeste imagem."

Como bem define Marlon Drees (Drees, 2007, p. 4), o primeiro Hino apresenta um "louvor do dia, mas um maravilhamento pela noite" ("Lob des Tages, aber Begeisterung für die Nacht"). A bem dizer, por mais sincero que seja todo esse louvor da luz, ele é em grande medida retórico, pois, a partir do segundo parágrafo, não tarda a ceder lugar a uma glorificação da noite que é ainda mais pungente e fervorosa que o louvor do dia:

Para além me volto, para a sacra, a indizível, a misteriosa noite. Longínquo, o mundo jaz - decaído para uma funda cripta - e ermo e solitário é o seu lugar. Nas cordas do peito sopra uma profunda nostalgia [melancolia, na tradução de Okamoto \& Allegrini]. Em gotas de orvalho me quero deixar afundar e misturar-me com a cinza. Longes da memória, anelos da juventude, sonhos da infância e os breves regozijos e esperanças vãs de toda uma vida tão longa vêm, com as suas vestes cinzentas como a névoa da tarde após o sol posto. A luz descerrou noutros espaços os seus álacres panais. Pois não havia ela de regressar para junto dos seus filhos, que a esperavam há muito com a fé da inocência? (Novalis, 1998, pp. 17 e 19).

Ao iniciar a frase com "abwärts" ("para além"), o poeta obtém o efeito contrastante de uma afirmação resoluta: ; "Para além me volto, para a sacra, a indizível, a misteriosa noite". 
Está implícito aqui um "no entanto" - "no entanto me volto para além..." (Okamoto \& Allegrini optam por "Entanto inclinome...") -, sugerindo-se nas entrelinhas que, apesar de todas as maravilhas reveladas pela luz, é para a noite que o sujeito se sente compelido, atraído por um fascínio que já se revela nos adjetivos "a sacra, a indizível, a misteriosa" noite. Segundo Fiama Brandão (Brandão, 1998, p. 11), a figura do "excelso Estrangeiro" que aparece no primeiro parágrafo evoca as concepções gnósticas dualistas do homem celeste expatriado na terra. Se pudermos associar o eu lírico à imagem do estrangeiro, como uma imagem externalizada sua, é então como se ele desse a entender que não está em casa na luz e na dimensão terrena, por mais que as ame, e por isso algo o atrai para a noite. Ao longo de todos os Hinos, a luz é de fato associada à Terra, enquanto a noite é associada a um "além" - "para além me volto, para a... Noite" -, ou seja, não se trata apenas da noite na Terra ou da Terra durante a noite, mas sim de uma dimensão em que o sujeito entra em contato com um outro mundo - um mundo no qual talvez o estrangeiro se sentisse em casa. Contudo, o que em um primeiro momento ocorre nessa passagem do primeiro para o segundo parágrafo não é nada como um contato com um outro mundo, mas sim um esvaziamento em que as maravilhas deste mundo, terreno, deixam de ser: "longínquo, o mundo jaz - decaído para uma funda cripta - e ermo e solitário é o seu lugar." Assim, embora o estrangeiro tenha se voltado para a noite talvez buscando nela o seu país natal celeste, neste momento ela só se apresenta negativamente, como ausência de luz neste mundo, o qual então surge em estado decaído. E na medida em que a luz morre, o eu lírico, não mais extasiado na visão daquele espetáculo, é também invadido por um sentimento de 
morte e abandono: essa noite negativa, limitada a suplantar o júbilo colorido que plenificava todos os seres durante o dia, traz uma sensação pesada, que o puxa para baixo, fazendo-o sentir no peito uma profunda melancolia e o desejo de se deixar "afundar em gotas de orvalho" e "misturar-se com a cinza". Ele é tomado então por "longes da memória, anelos da juventude, sonhos da infância e os breves regozijos e esperanças vãs de toda uma vida", os quais vêm "com as suas vestes cinzentas como a névoa da tarde após o sol posto". Ou seja, enquanto a luz rejubilava o ser presente, a vida em sua pura afirmação de ser - "a suave onipresença do seu dia que desponta", "somente pela sua presença desvela toda a maravilha dos impérios do mundo" - a noite traz uma atmosfera nostálgica, do ser que não é: do que foi um dia promessa e terminou se mostrando vão ao longo da vida; algo que não tem a realidade de um presente vivo; uma espécie de vazio entre o passado e o futuro. É uma experiência de morte o que a noite traz aqui. Morte que, até esse momento, possui um sentido exclusivamente negativo.

Todavia, em um movimento radical, esse aspecto negativo será no terceiro parágrafo contraposto por uma dimensão inquestionavelmente positiva:

O que é que, de repente, pleno de pressentimentos, brota de sob o coração e sorve a doce aragem da melancolia? Também em nós te comprazes, obscura Noite ["Também és benevolente para nós, escura Noite?", na tradução de Okamoto \& Allegrini]. O que é que tu guardas debaixo do teu manto, que me toca a alma com uma força invisível? Um bálsamo precioso goteja da tua mão, de um molho de papoilas. Elevas 
as pesadas asas do nosso ânimo. Sentimo-nos obscuramente, inexprimivelmente comovidos. Vejo, numa crispação de alegria, um rosto grave, que para mim se inclina suave e pensativo, e até mim traz, por entre infinitas madeixas ondeadas, a tão doce juventude materna. Tão pobre e tão pueril me parece agora a luz que júbilo e que bênção, ao despedir-se o dia - Assim, só porque a Noite aparta de ti seus servidores, semeaste na lonjura do espaço as esferas luminosas, para que testemunhassem da tua omnipresença - do teu regresso - no tempo do teu afastamento. Mais celestes do que aquelas estrelas cintilantes nos parecem os olhos infinitos que a Noite em nós abre. E eles veem, mais longe do que os mais ténues desses inuméraveis exércitos - sem necessitarem de luz para penetrarem na profundidade de um espírito que ama - e indizível júbilo preenche assim um altíssimo espaço. Glória à rainha do mundo, à grande mensageira de mundos sagrados, a do amor extasiado - é ela que te envia até mim - doce amada - amável sol da noite - eis que estou desperto - porque sou teu e sou meu - revelasteme a Noite como Vida - tornaste-me humano - devora de ardor espiritual o meu corpo para que, etéreo, eu possa misturar-me contigo mais intimamente, e seja então eterna a nossa noite de bodas (Novalis, 1998, pp. 19 e 21).

Logo no começo desse parágrafo, o peso suscitado pela noite vem a ser aliviado por ela própria, e as esperanças da juventude que se mostravam vãs são agora suplantadas por um pressen- 
timento mais elevado, mais profundo, trazido pela noite. Vale observar a proximidade entre 'esperança' e 'pressentimento': movimento do espírito em direção ao futuro, pleno de boas expectativas. A noite resguarda algo de invisível à luz do dia, algo que agora se pressente, e isso só é sentido pelo eu lírico na medida em que ele experimenta a queda do mundo diurno, na medida em que experimenta a noite como morte. É somente após essa queda, somente após entrar no estado de espírito nostálgico e melancólico, que a noite inicia no eu lírico um processo de ascensão. Segundo Drees (Drees, 2007, p. 5), Novalis empregaria aqui a metáfora de uma gravidez, "que no Pietismo possui o significado de um renascimento místico, bem como iniciação em outra realidade, mais alta." É então que reconhece a noite como noite materna: "Vejo, numa crispação de alegria, um rosto grave, que para mim se inclina suave e pensativo, e até mim traz, por entre infinitas madeixas ondeadas, a tão doce juventude materna". E logo toda a riqueza do dia se mostra inferior à da noite, a ponto de ele exclamar: "tão pobre e tão pueril me parece agora a luz que júbilo e que bênção, ao despedir-se o dia..."; arrebatado, ele dirá que "a Noite abre em nós olhos infinitos", olhos que veem mais longe do que os olhos diurnos e finitos, pois não "necessitam de luz para penetrarem na profundidade de um espírito que ama". A noite instaura assim um "indizível júbilo [que] preenche um altíssimo espaço" - júbilo maior que o do dia, espaço mais alto que o da Terra. Essa é a noite positiva: não a morte da beleza do mundo iluminado, mas uma dimensão que contém uma beleza e profundidade superiores, e agora é louvada pelo eu lírico como "a rainha do mundo, a grande mensageira de mundos sagrados, a do amor extasiado". Se o amor havia sido mencionado no primeiro parágrafo como o amor dos seres pela luz, ele 
aqui ganha um sentido mais intenso, pois agora é o amor do eu lírico que, através da noite, se endereça à amada morta, ou melhor, a amada é trazida pela noite: "é ela [a Noite] que te envia até mim - doce amada - amável sol da noite". Sabemos que Novalis escreveu os Hinos após a morte de sua jovem noiva Sophie, experiência que ele próprio declara tê-lo convertido a uma aceitação incondicional da morte, vislumbrando nesta a passagem para um estado superior, a "verdadeira vida". Brandão observa a esse respeito que o pseudônimo Novalis assumido por Friedrich von Hardenberg é muito mais que um nome literário: seria o novo nome que tradicionalmente acompanha o renascimento de um iniciado. Esse movimento de iniciação em Novalis se dá justamente mediante a perda da amada, que teria sofrido "a morte necessária" para posteriormente entregar-se ao noivo renascido, "como a um justo" (Brandão, 1998, p. 10). É o amor, portanto, quem protagoniza essa verdadeira conversão na qual a vida terrestre e a luz diurna, em uma palavra o mundo visível, se mostram opacos perante a vida espiritual da noite, dimensão do invisível. E, sendo o amor o protagonista dessa conversão, as coisas como que se invertem: se a noite enviou a amada, é a amada que, como luz na escuridão, "sol da noite", faz o eu lírico compreender a dimensão da noite: "revelaste-me a Noite como Vida - tornaste-me humano". Na medida em que a noite é aqui a dimensão em que a amada morta habita, a frase "revelaste-me a Noite como Vida" pode ser lida como "revelaste-me a Morte como Vida". Morte como transfiguração, como ascensão a uma vida superior, espiritual - segundo Brandão (Brandão, 1998, p. 11), a noite da tradição mística e iniciática, o tempo do Sol espiritual (sol que para Novalis coincide com a amada morta). Morte, portanto, cujo sentido é mais positivo que a vida, pois 
significa eternidade, e que será cantada no sexto e último Hino, o poema intitulado "Nostalgia da Morte" [Sehnsucht nach dem Tode]. Assim, o primeiro Hino termina com a exortação lançada à amada: "devora de ardor espiritual o meu corpo para que, etéreo, eu possa misturar-me contigo mais intimamente, e seja então eterna a nossa noite de bodas." Reunindo-se a ela, o eu lírico se reintegraria ao universo na totalidade. Uma verdadeira união mística, cuja dimensão é a noite. Heinz Ritter (Ritter, 1930, p. 100) destaca que o mundo interior do sujeito lírico começa a se manifestar a partir do contato com a noite; primeiramente sob a forma negativa da melancolia, das lembranças e nostalgias, mas logo também como o lugar em que se resguarda o amor. A noite seria nesse sentido a dimensão do mundo interior, enquanto que o mundo exterior seria prerrogativa do dia. E justamente essa interioridade está unida ao interior profundo do próprio universo: é na e pela noite que o interior do sujeito se reconhece no universo, sugerindo-se sua unidade e o caminho para a reunificação.

Essa positividade da noite será mais e mais aprofundada nos hinos seguintes. Embora não seja possível aqui acompanhar em detalhe esses desdobramentos na sequência da obra, cabe mencionar alguns pontos significativos para o propósito deste artigo. No segundo Hino, a oposição entre dia e noite se intensifica, na medida em que até mesmo a potência da luz como geradora da vida será agora considerada de maneira negativa, como ciclo de nascimento e morte, portanto como âmbito da transitoriedade, que será contraposto à dimensão infinita e perene da noite: "O tempo da Luz é mensurável; mas o império da Noite é sem tempo e sem espaço". O eu lírico fala então da "jornada terrena" na qual "se consagra à Noite" (Novalis, 1998, p. 23), e que soa 
como o caminho que o excelso estrangeiro tem de trilhar para poder retornar ao seu país natal celeste. O Terceiro Hino revela a visão diante do túmulo da amada; visão que novamente realiza um movimento de ascensão, em que o eu lírico, encontrando-se em estado de completo abandono e desesperança diante do túmulo, logo vislumbra um outro mundo, trazido pelo crepúsculo e que vem a romper "os vínculos do nascimento - a cadeia da Luz": o mundo da noite, eterno, e no qual se encontra a amada (Novalis, 1998, pp. 25 e 27). No quarto Hino, a dimensão da noite eclipsa completamente a luz do dia, sendo considerada seu próprio fundamento: "Ter-te-ias anulado em ti própria (eu lírico interpelando a luz/dia) - ter-te-ias perdido no espaço sem fim, se ela (a noite) não te sustivesse e não enlaçasse, para te acalentar, para que, em chamas, engendrasses o mundo" (Novalis, 1998, p. 33). Este hino termina com um presságio, segundo o qual a noite se tornará absoluta no momento em que a própria luz se juntar aos adoradores da noite, quando também ela "apagar e morrer de saudade e íntimo ardor" (Novalis, 1998, p. 33). O quinto Hino quebra a sequência linear dos quatro primeiros ao narrar um mito, nitidamente inspirado na mitologia grega, de uma época em que a Terra teria sido o reino de uma luz soberana, e os deuses apenas rejubilavam as belezas e alegrias desse tempo imemorial; no entanto, em dado momento, essa exuberância teria sido abalada pelo pensamento da morte, ocasionando uma fuga dos deuses, que teriam sido encobertos pelo véu da noite. Naquele tempo, a noite era negada com temor. Mas então Cristo teria vindo para ensinar aos homens, através de sua morte e ressurreição, o sentido profundo da noite como dimensão da vida eterna, o sentido da morte como ascensão espiritual, fundando assim uma nova era. Com isso, a experiência 
de ascensão, o renascimento pela noite, que até o quarto Hino diziam respeito ao eu lírico individualmente, amplia-se agora para a humanidade como um todo. Tudo isso conflui para uma união mística total no sexto e último Hino, o poema Sehnsucht nach dem Tode, em que se unem o amor da amada, de Cristo e de Deus:

Descer até a doce Noiva, Até Jesus - nosso Amado.

A paz de quem ama e sofre É sol poente iluminado.

Um sonho desprende laços,

O Pai nos cinge nos braços!

Ainda que a imagem seja de queda - Hinunter zu der süssen Braut ("descer até a doce Noiva"); Und senkt uns in des Vater Schooss ("e nos faz afundar no regaço do Pai"), ela soa em sentido inteiramente positivo, como um acolhimento e uma fusão absolutos. Não há nada que aqui se oponha ao sentido de ascensão trabalhado por Novalis ao longo dos Hinos. Em verdade, é possível ler essa imagem final de "queda" como uma espécie de síntese: ao ser a cada Hino conduzido pelo sonho e elevado através da noite para a dimensão da vida eterna, para a amada, para Jesus e para Deus, ao final o eu lírico (que agora já abrange a humanidade inteira) se entrega, se solta completamente - Ein Traum bricht unsre Banden los ("Um sonho desprende nossas amarras") - e se abandona confiante (getrost) ao abraço da morte. Parece que a morte mesma se converte na dimensão ansiada pelo eu lírico, pois tudo está plenamente unido. 


\section{A noite desolada de Trakl}

O sentimento de perda da dimensão acolhedora da noite surge em poemas de Trakl frequentemente sob a forma de suspiros e lamentos; como em "Canto do desterrado" (Gesang des Abgeschiedenen): "Ah, morar no azul animado da noite" (Trakl, 2010, p. 71), e no "Cântico da Noite" (Gesang zur Nacht): "Céu [noturno] em que já não florescem deuses (Trakl, 1992, p. 35). Poder-se-ia explorar a presença desse sentimento de perda como uma constante na lírica trakliana, para além das passagens em que ela é evidente, na medida em que se trata, justamente, da presença de uma ausência. Ciente de seu romantismo desenganado, esse admirador e herdeiro de Novalis dialoga com o poeta dos Hinos à Noite, a exemplo do poema "A Novalis" (An Novalis, $2^{\mathrm{a}}$. versão):

Embora esse poema faça referência à morte precoce de Novalis - aos 28 anos e em seu auge literário -, Cavalcanti observa com razão que Trakl parece referir-se a si mesmo (Cavalcanti, 2010, p. 101), que viria a morrer aos 27 anos. De fato é como se ele fosse Novalis em um mundo no qual ainda canta a "flor azul", esse símbolo supremo do desejo romântico de uma fusão com o todo, cunhado por Novalis, com a diferença de que agora a noite não mais a acolhe. O desejo de acolhimento na noite persiste, mas não mais existe o acolhimento. A noite será em Trakl, então, predominantemente o âmbito de aparições terríficas: " $\mathrm{E}$ o poço negro que é a minha alma/Gerou imagens de noites tenebrosas..." (Trakl, 1992, p. 23), "Noite, muda porta do meu sofrimento..." (Trakl, 1992, p. 31), "Volta de novo a noite e um mortal se lamenta..." (Trakl, 2010, p. 17), "À noite encontrei-me num pântano/ Coberto de lixo e pó de estrelas..." (Trakl, 2014, 
p. 27). Para uma análise comparativa da dimensão da noite em Trakl em relação aos Hinos à Noite de Novalis, é especialmente interessante tomar para consideração um poema que, tal como o primeiro Hino de Novalis, narra o movimento de passagem do dia à noite. Esse movimento é especialmente nítido no poema "Ocaso" (Untergang):

Sobre o lago branco

Partiram os pássaros selvagens.

No crepúsculo sopra de nossas estrelas um vento gelado.

Sobre os nossos túmulos

Inclina-se a fronte despedaçada das trevas.

Sob carvalhos, balançamos numa barca prateada.

Sempre ressoam os muros brancos da cidade.

Sob arcos de espinhos

Oh, irmão, ponteiros cegos, escalamos rumo à meianoite.

(Trakl, 2010, p. 57, trad. Cláudia Cavalcanti).

O título do poema já revela o foco dado pelo poeta: o anoitecer pela ótica da queda. Untergang significa literalmente "queda", "declínio" - "ocaso" quando associada à passagem do dia para a noite -, e, considerando que ela não é das palavras mais usuais em alemão para referir-se ao anoitecer (Trakl poderia ter usado Dämmerung [crepúsculo], p. ex.), pode-se supor que é aqui intencionalmente usada com o intuito de provocar associações negativas. 
$\mathrm{Na}$ primeira estrofe temos a imagem espiritualizada de um lago branco, sugerindo uma placidez que, no entanto, será imediatamente contrastada com a imagem dos pássaros selvagens partindo sobre ele. Esse contraste pode ser sentido de modo abrupto se interpretarmos o lago branco como uma ambiência de paz espiritual que é quebrada pelo rumor selvagem da natureza (os pássaros) e pelo vento gelado que sopra das estrelas. Mas o lago também pode ser branco por já refletir a luz prateada da lua que chega com a noite, e seria nesse caso um lugar de passagem, ou refletiria uma passagem - do dia para a noite, da vida para a morte -, passagem simbolizada pela fuga dos pássaros que são atraídos para a noite (para a morte?). Nesse último sentido, o contraste seria antes uma intensificação no próprio movimento de partida realizado sincronicamente pela fuga do dia e dos pássaros no crepúsculo e refletido na brancura prateada do lago lunar; coroado pelo sopro frio das estrelas, esse conjunto de imagens termina por compor uma forte atmosfera de abandono.

Mas é no segundo parágrafo que esse movimento ganha um nítido sentido de morte: "Sobre os nossos túmulos/ Inclina-se a fronte despedaçada das trevas". "Os nossos túmulos" podem estar no presente ou no futuro, e o impacto aqui está justamente em afirmar, no presente, que os túmulos (futuros) já são nossos: são-nos destinados. É possivelmente este o sentido do pronome possessivo no verso anterior - "No crepúsculo sopra de nossas estrelas um vento gelado": "nossas estrelas" pode ser uma metáfora para "nosso destino", ou seja, a morte; destino que as estrelas prenunciariam em seu sopro gelado. Vale lembrar que as lápides dos túmulos costumam ser de cor branca ou cinza, propícias para refletir a luz prateada da lua e, assim, revelar a frieza da 
morte; luz que, portanto, não tem mais o sentido positivo do "sol da noite" de Novalis. E é para a morte que as trevas nos envolvem, ao inclinar para nossos túmulos a sua "fronte despedaçada". Caberia aqui uma comparação pontual com o momento em que o eu lírico novalisiano descobre a noite como mãe acolhedora. Enquanto este vê, "numa crispação de alegria", um "rosto grave" inclinar-se "suave e pensativo" para ele, trazendo-lhe, "por entre infinitas madeixas ondeadas, a tão doce juventude materna", o inclinar-se das trevas sobre nossos túmulos em "Ocaso" nada tem de maternal: a noite envolve o eu lírico não com amor, mas com frieza mortal - imagem semelhante surge no poema "Grodek", em que "a noite envolve guerreiros em agonia" (Trakl, 2010, p. 79). Enquanto isso, "Sob carvalhos, balançamos numa barca prateada". O carvalho é considerado uma árvore sagrada em diversas tradições, simbolizando a divindade e por vezes desempenhando o papel axial de comunicação entre Céu e Terra (Chevalier \& Gheerbrant, 1989, p. 195). A expressão "sob carvalhos" pode aludir à pequenez do homem, sobre quem se avultam as sombras de carvalhos imponentes, que neste caso estariam representando um aspecto temível das forças da natureza e/ou de forças divinas que ultrapassam o homem. Mas a imagem mais fundamental dessa estrofe parece residir na barca prateada. Ela talvez simbolize a busca de espiritualização por parte do homem, sua tentativa de construir algo sagrado - frágil construção que, instável, balança em um mar adverso. Lembremos também a barca da passagem conduzida por Caronte que, segundo a mitologia grega, levava as almas dos recém-mortos para o Hades. Entretanto, em um sentido ainda mais tenebroso do que a barca da passagem, a barca do poema pode também ser já o nosso túmulo, dentro do qual navegamos enquanto vivemos, mas que já 
está destinado a nos encerrar no fim.

$\mathrm{Na}$ terceira estrofe o branco-reflexo ressurge sinestesicamente: "Sempre ressoam os muros brancos da cidade" - de novo a brancura lunar e gelada domina o cenário, que agora é como que encerrado dentro de limites pela imagem dos muros da cidade. É possível que esse encerramento tenha aqui o mesmo sentido dos túmulos e da barca considerada como túmulo: os muros, caiados de branco, soam como um grande túmulo, uma barcatúmulo da humanidade. "Sob arcos de espinhos/ Oh, irmão, ponteiros cegos, escalamos rumo à meia-noite." O leitor é incluído pelo eu lírico, que o chama de irmão, ressaltando com isso a nossa igualdade de condição; talvez já uma alusão cristã, no sentido de irmãos homens, mortais, cujo destino é "escalar sob arcos de espinhos rumo à meia-noite", o que soa como um verdadeiro sacrifício, uma cruz. Escalar rumo à meia-noite é escalar para a morte. Importante observar que o verbo "escalar" [klimmen] não tem aqui o sentido de ascese, mas antes de esforço: subir debaixo de espinhos, para no fim afundar na morte, ou seja, a existência humana é esforço que termina sem transcendência, é carregar a cruz em vão. E o fazemos como "ponteiros cegos", porque o tempo avança em direção a esse destino de modo inevitável.

Em todo o poema, é digna de nota uma escolha formal feita por Trakl: a repetição das preposições unter [sob] e über [sobre], gerando a sensação de um campo de força que se levanta sobre nós humanos, completamente opressos sob esse jugo. Essa sensação é particularmente intensa na medida em que se realiza por completo na imagem do túmulo: como se de certo modo já fôssemos sendo "soterrados" em vida, enquanto ainda navegamos em nossa barca prateada, fadada a fechar-se sobre nós ao fim. 
Todo o poema parece ampliar uma experiência que, no primeiro Hino de Novalis, surge como uma etapa que será superada: a chegada da noite como um esvaziamento, como uma atmosfera de morte e abandono. É como se Trakl estacasse naquele instante em que, no primeiro Hino, o mundo "jaz longínquo", "decaído para uma funda cripta - e ermo e solitário é o seu lugar", sem uma superação ou transcendência possíveis. A meia-noite rumo à qual escalamos se reduz ao vazio, ao completo aniquilamento. No poema XII que desfecha o ciclo "Cântico da Noite" (de 1909), podemos observar a noite como vazio e aniquilamento de maneira particularmente explícita:

Tu és em funda meia-noite

Uma praia morta num mar de silêncio,

Uma praia morta: Esquecimento!

Tu és em funda meia-noite.

Tu és em funda meia-noite

O céu em que foste estrela por vezes,

Céu em que já não florescem deuses.

Tu és em funda meia-noite.

Tu és em funda meia-noite

Um não-concebido em ventre de amor,

O que nunca foi e não tem ser!

Tu és em funda meia-noite.

(Trakl, 1992, p. 35, trad. João Barrento)

O eu lírico fala ao leitor, ou a si mesmo, como quem profere uma sina. Se lermos o primeiro verso como uma frase por si, 
"Tu és em funda meia-noite", ela soa como a determinação irrevogável de um destino, a determinação do que ele próprio, o leitor e por princípio todo homem tem de ser: ser em funda meia-noite. Esse tom de sina vai-se intensificando a medida que cada uma das três estrofes termina com essa mesma sentença como frase isolada. A noite é o lugar do nosso verdadeiro, profundo ser; o que, tomado isoladamente, constitui uma visão tão romântica quanto a de Novalis, que vê no dia um azáfama a encobrir e interromper o ser invisível e profundo que só a noite revela. Entretanto, Novalis ultrapassa rapidamente a atmosfera de abandono propiciada pela chegada da noite para nela descobrir o infinito, o amor e a vida eterna. Em Trakl, o adjetivo "funda" em "funda meia-noite" possui um sentido exclusivamente aterrador: na meia-noite é-se "uma praia morta num mar de silêncio", é-se esquecimento. Na segunda estrofe, surgem ecos de um tempo romântico - que pode ser o tempo histórico do Romantismo ou uma infância ideal - como lamentos por uma grande perda: "o céu em que foste estrela por vezes", "céu em que já não florescem deuses". A perda é uma presença, a presença de uma ausência, que habita como um vazio essa funda meia-noite, ferida aberta e abissal. A terceira estrofe desfecha o poema ao pronunciar uma espécie de decifração para as anteriores: "[tu és] um não-concebido em ventre de amor", "o que nunca foi e não tem ser!" - pode-se ler aqui um sentido de origem, nossa proveniência a partir do nada, do não-ser. Se não podemos nos remeter a uma concepção em ventre de amor, ou seja, se não somos filhos de Deus, se a noite da qual proviemos não é uma mãe amorosa que nos concebeu e que voltaria a nos acolher em nossa morte, então somos uma praia morta, habitamos o completo vazio, nossa essência é esquecimento e nosso ser 
é um não-ser. A "funda meia-noite" exprime o abismo de nosso ser, nossa condição de insuperável queda no nada.

A imagem do anoitecer como queda se repete na lírica de Trakl, inclusive pela recorrência de expressões como "queda" e "ocaso" (Untergang e Verfall), geralmente relacionadas ao anoitecer. Associada à queda, é frequente também a imagem do afundamento, como se uma força gravitacional terrível e insuperável sempre nos puxasse para baixo. Além dos poemas "Ocaso" e "Cântico da Noite XII" podemos ler em sua obra inúmeras alusões a essa imagem: "Há um barco vazio, que à noite desce o negro canal..." (Trakl, 2010, p. 25), "À noite a água branca desce às urnas tumulares..." (Trakl, 2010, p. 31), "Vê, um barco temeroso afunda/ Sob estrelas,/ E a muda face da noite" (Trakl, 2014, p. 77). Walther Killy destaca no poema Helian a imagem do carrilhão que não soa mais - "à noite afunda um carrilhão que já não soa" (Am Abend versinkt ein Glockenspiel, das nicht mehr tönt): "o carrilhão há muito já não chama à oração, não o suficiente, ele afunda na noite" (Killy, 1960, p. 10). Contudo, essa queda e afundamento não é necessariamente para o vazio absoluto, ou antes: o vazio não é necessariamente um nada absoluto, mas pode ser uma negatividade que se revela como dor e destruição: "Noite, muda porta do meu sofrimento, / Olha o meu sangue negro da chaga a correr, / E como já se inclina o cálice da dor!" (Trakl, 1992, p. 31), "Olha! já escurece./ Volta de novo a noite e um mortal se lamenta/ E com ele sofre um outro" (Trakl, 2010, p. 17). O poema "A Melancolia" (Die Schwermut) retrata de maneira explícita esse sentido destrutivo que se consuma na passagem do dia para a noite:

És poderosa, boca escura, 
No íntimo, imagem formada

De nuvens de outono,

Silêncio dourado da tarde;

Grande corrente de brilho verde

Na região de sombras,

De pinheiros quebrados;

Um lugarejo

Que desfalece abnegado em imagens marrons.

Eis que saltam os cavalos negros

Em prado brumoso.

Soldados!

Da colina onde o sol rola morrendo

Jorra o sangue que ri -

Sob carvalhos

Atônitos! Oh, rancorosa melancolia

Do exército; um elmo cintilante

Caiu tilintando de fronte purpúrea.

Noite outonal vem tão fresca,

Brilha com estrelas

Sobre quebradas ossadas de homens

A silenciosa monja.

(Trakl, 2010, p. 75, trad. Claudia Cavalcanti)

É narrado o desenrolar de uma batalha de guerra que acontece em uma espécie de conspiração terrífica entre a natureza violenta e a "rancorosa melancolia do exército"; o que fica sobremodo claro nos versos "Da colina onde o sol rola morrendo/ Jorra o sangue que ri", como se o sangue derramado na batalha proviesse de uma força malévola da natureza, que chega a 
comprazer-se (o sangue que ri) com a carnificina; como bem expresso por Rolleston, "esse derradeiro levante dionisíaco funde o humano com o cosmos em voluntária destruição" (Rolleston, 2005. p. 188). Na imagem do sol que rola morrendo se condensa todo o sentido de queda na passagem do dia à noite, queda violenta e que se dá em uma atmosfera triunfante da natureza. A queda está na dimensão do humano, enquanto o triunfo pertence àquilo que sobrepassa o homem: as forças do universo, a natureza. Esse contraste pode ser lido na conclusão do poema: "Noite outonal vem tão fresca,/ Brilha com estrelas/ Sobre quebradas ossadas de homens/ A silenciosa monja". O homem é posto por terra, mas enquanto isso a "silenciosa monja" se ergue soberana sobre as ossadas quebradas dos homens; trata-se, certamente, da lua, pois Trakl joga com a semelhança das palavras alemãs para "lua" e "monja", respectivamente Mond e Mönchin. Monja silenciosa que brilha diante da destruição, a lua aquiesce friamente com o mal da guerra, enquanto preserva sua aura sagrada. A noite vem, assim, como um coroamento do mal, chegando a revelar uma espécie de consentimento com o mal por parte de um universo incólume e indiferente ao sofrimento humano.

Em todos esses poemas, podemos observar o oposto do que ocorre em Novalis: em vez de a noite favorecer uma união mística do sujeito com o universo, ela se mostra como um ambiente hostil de abandono e destruição, de uma morte sem transcendência, em que toda aspiração espiritual é ignorada pela frieza da noite, da lua, das estrelas; frieza que nenhuma semelhança tem com a noite maternal de Novalis. O Universo não se sustenta e não se mantém unido como criação de Deus, os homens não são salvos por Cristo, e assim tampouco há esperança para o 
amor dos amantes: "Nesta noite em travesseiros mornos soltamse/ Amarelados de incenso os membros frágeis dos amantes..." (Trakl, 2010, p. 27). Com muita exatidão conclui Barrento que, em vez de uma união, o que há em Trakl é uma disjunção mistica (Barrento, 1992, p. 11).

\section{Considerações finais}

A observação de Inga Bartels (Bartels, 2010, p. 3) de que o sonho é um motivo particularmente interessante de se pesquisar em forma comparativa entre autores de diferentes épocas bem pode valer para a noite - à qual de resto o sonho, é claro, está intimamente relacionado -, na medida em que as mudanças de direção em seu tratamento podem revelar profundas transformações não apenas em seu próprio sentido, como também no conjunto de temas e questões nas quais se envolvem os autores de épocas distintas. Esse procedimento parece funcionar especialmente bem no caso de Novalis e Trakl, por ambos pertencerem a uma mesma tradição - a da moderna poesia lírica alemã - e por ao mesmo tempo essa pertença comum apresentar uma profunda fratura, inevitável porque em grande medida reflexo das questões de seus momentos específicos.

Expoente maior do Primeiro Romantismo alemão na virada do XVIII para o XIX, Novalis logrou condensar nos seus Hinos à Noite as aspirações fundamentais do romantismo: a nostalgia de infinito (Sehnsucht) cujo objeto último seria uma reintegração ao Universo, e que no caso de Novalis se coloca juntamente com o anseio por um reencontro com Cristo, culminando em uma união mística com Deus. Nisso se destaca sobremodo o papel missionário do homem no Universo, que nos Hinos se configura 
como a tarefa de se consagrar à noite e buscar, para muito além do mundo visível revelado pela luz, o reino espiritual e invisível do infinito que se resguardaria sob o manto amoroso da noite. Mais do que dar expressão a esse imenso desejo, pode-se dizer que os Hinos à Noite o realizam poeticamente, conferindo à poesia um sentido metafísico e uma força de realização que lhes seriam irremissíveis. Seria esta uma qualidade órfica própria da poesia, que por isso mesmo seria um caminho privilegiado para a misteriosa passagem à morte. Em nossa leitura, dedicamos especial atenção ao movimento de passagem do dia à noite no primeiro Hino de Novalis (e indicando sucintamente sua continuação na obra) como correspondente a um movimento de ascensão do eu lírico à dimensão espiritual. Esse movimento revela algo caracteristicamente romântico a que poderíamos chamar de enlevo: o sujeito se deixa suspender e levar, como em um sonho, até uma dimensão superior em que se resguarda o amor e o espírito; movimento ascensional que prossegue rumo a um fim apoteótico e epifânico.

Ao nos depararmos com a figuração da noite na lírica de Georg Trakl podemos ver que não apenas ocorre uma mudança de sentido, mas sobretudo que essa mudança de sentido reflete uma perda do sentido anterior, positivo da noite. Como todo autor do século XX, Trakl não poderia ser um romântico em sentido estrito tal como Novalis; seu contexto histórico (do qual a Primeira Guerra mundial é uma dentre inúmeras circunstâncias) não o permitiria a não ser sob a forma de um ingênuo anacronismo. No entanto, a sensibilidade de Trakl é essencialmente romântica, e o modo como esse romantismo ganha voz é através dos lamentos e dos silêncios que acompanham seus cenários de desolamento e destruição. Existe um sentimento órfão em rela- 
ção à noite, o sentimento de que era ela quem tinha de acolher o espírito, e seu não-acolhimento, devido a tal expectativa, termina por significar muito mais do que uma indiferença neutra: passa a revelar imagens terríficas e a significar por vezes até mesmo, como vimos em "A melancolia", um consentimento maligno do universo, na figura da noite, com o sofrimento humano. A noite deixa de representar uma transcendência espiritual última, a Terra é abandonada à sua dimensão terrena e, com ela, o homem. Em vez de surgir como mensageira de um outro mundo, sagrado, a noite se mostra como um domínio no qual a desesperança do mundo terreno se torna mais patente. Em vez de favorecer uma fusão com o universo, a dimensão da noite passa a exprimir a impossilidade dessa fusão, tornando-se o lugar de uma completa desagregação de toda expectativa espiritual. A queda em Trakl é tão pungente porque é a queda de um desejo que, um século antes, estava em plena ascensão. Em compasso com isso, resta à poesia plasmar uma beleza lírica que seja capaz de refletir a destruição que se percebe no mundo e, ao mesmo tempo, soar como o lamento de anseios cientemente impossíveis.

\section{Referências Bibliográficas}

BARRENTO, J. "Georg Trakl: o mosaico da morte". In: TRAKL,

G. Outono Transfigurado. Porto: Assírio e Alvim, 1992.

BARTELS, I. Der Traum in der romantischen Literatur am Beispiel von Novalis' „Heinrich von Ofterdingen“. Grin Verlag, 2006.

BRANDÃO, F. "O nome, os Hinos." In: NOVALIS. Hinos à Noite. Prefácio e tradução de Fiama Hasse Pais Brandão. Lisboa: Assírio \& Alvim, 1998.

CAVALCANTI, C. "Emergir das profundezas de G. T.: uma ten- 
tativa". In: TRAKL, G. De Profundis. São Paulo: Iluminuras, 2010.

CHEVAliER, J.; GHEERBRANT, A. Dicionário de Símbolos. Rio de Janeiro: José Olympio, 1989.

DREES, M. Zwischen Kunst und Gott. Zu Novalis 'Hymnen an die Nacht'. Norderstedt: Grin Verlag, 2007.

KILLY, W. Über Georg Trakl. Göttingen: Vandenhoeck \& Ruprecht, 1960.

NOVALIS. Hinos à Noite. Prefácio e tradução de Fiama Hasse Pais Brandão. Lisboa: Assírio \& Alvim, 1998.

Nilton N. Okamoto e Paulo Allegrini. Mairiporã: A Esfinge, 1987.

RITTER, H. Novalis' Hymnen an die Nacht. Ihre Deutung nach Inhalt und Aufbau auf Textkritischer Grundlage. Heidelberg: Carl Winters Universitätsbuchhandlung, 1930.

ROLleStON, J. "Choric Consciousness in Expressionist Poetry". In: A Companion to the Literature of German Expressionism. Ed.: Neil H. Donahue. New York: Camden House, 2005.

TRAKL, G. Das Dichterische Werk auf Grund der historischkritischen Ausgabe von Walther Killy und Hans Szklenar. München: Deutscher Taschenbuch, 2014. . De Profundis. São Paulo: Iluminuras, 2010.

- Outono Transfigurado. Tradução e prefácio de João Barrento. Porto: Assírio e Alvim, 1992. 